Jurnal Ilmiah Pendidikan Matematika p.ISSN:2303-3983 e.ISSN:2548-3994

Vol. 6 No. 1 Januari 2018 Hal. 17-20

\title{
ANALISIS RESPON MAHASISWA TERHADAP MEDIA PEMBELAJARAN BERBASIS EDMODO PADA MATA KULIAH PEMROGRAMAN KOMPUTER
}

\author{
NURINA HIDAYAH \\ Pendidikan Matematika Universitas Pekalongan \\ nurihidayah.matematika@gmail.com \\ SAYYIDATUL KARIMAH \\ Pendidikan Matematika Universitas Pekalongan \\ sayyidatulkarimah@gmail.com \\ RINI UTAMI \\ Pendidikan Matematika Universitas Pekalongan \\ utamirini31@gmail.com
}

\begin{abstract}
Abstrak
Analisis respon mahasiswa dalam penelitian ini bertujuan untuk mengetahui kualitas produk media pembelajaran berbasis Edmodo yang telah dikembangkan. Hasil yang diperoleh rata-rata menunjukkan $81 \%$ hal ini menunjukkan respon positif dari mahasiswa. Hal yang paling menonjol dari enam indikator yang digunakan adalah senang dan menarik. Pernyataan dari indikator senang yaitu pembelajaran dengan media pembelajaran berbasis Edmodo membuat mahasiswa senang mencapai $88 \%$. Sedangkan pada indikator menarik menyatakan media pembelajaran berbasis Edmodo merupakan hal baru dalam perkuliahan.
\end{abstract}

Kata kunci: media pembelajaran, Edmodo, Pemrograman Komputer

\begin{abstract}
Analysis of student responses in this study aims to determine the quality of Edmodo-based learning media products that have been developed. The results obtained on average show $81 \%$ of this indicates a positive response from students. The most prominent of the six indicators used are happy and interesting. The statement of happy indicator that is learning with learning media based on Edmodo make student happy to reach $88 \%$. While the interesting indicator states Edmodo-based learning media is new in the lecture.
\end{abstract}

Keywords: Learning media, Edmodo, Pemrograman Komputer

\section{Pendahuluan}

Seorang duru (dosen) harus mampu memberikan fasilitas belajar kepada mahasiswanya. meskipun mengajar dan belajar merupakan dua proses yang berdiri sendiri, keduanya saling berkaitan. Guru memberikan fasilitas belajar dan mahasiswa menggunakan kesempatan untuk belajar. Pembelajaran yang sukses juga membutuhkan perencanaan yang baik. Salah satu perencanaannya dapat berupa pembuatan media pembelajaran.

Media pembelajaran merupakan perantara yang digunakan oleh dosen dalam membantu menyampaikan materi. Hal ini diperlukan apabila materi yang sulit untuk divisualisasikan serta bersifat abstrak. Salah satunya adalah mata kuliah Pemrograman Komputer.

Mata kuliah Pemrograman Komputer merupakan salah satu mata kuliah yang ditawarkan di program studi Pendidikan Matematika Fakultas Keguruan dan Ilmu Pendidikan 
Universitas Pekalongan. Mata kuliah ini membahas tentang program-program yang ada untuk digunakan dalam penyusunan multimedia pembelajaran. Multimedia itu sendiri tersusun atas beberapa hal mulai dari teks, video, suara, animasi, dan interaktif. Menurut Marshall terdapat empat karakteristik suatu multimedia yaitu 1) sistem yang dikontrol oleh komputer; 2) sebuah sistem yang terintegrasi; 3) informasi yang ditangani direpresentasikan secara digital; 4) antarmuka pada media tampilan akhir biasanya bersifat interaktif Binanto, 2010. Salah satu program yang digunakan dalam mengembangkan multimedia tersebut yaitu VideoScribe.

VideoScribe merupakan gaya animasi yang digunakan untuk menyusun whiteboard animation. Whiteboard animation adalah media komunikasi yang dibuat oleh si pengirim kepada penerima pesan melalui simbol-simbol yang ada. Adanya penggunaan simbolsimbol seperti kata-kata, kalimat disertai gambar dan audiovisual akan membantu penerima dengan mudah memahami apa yang hendak dipesankan oleh pengirim. Sehingga dalam hal ini diperlukan kreativitas yang cukup dalam mengembangkan multimedia yang ada.

Oleh karena itu pembelajaran pada mata kuliah Pemrograman komputer perlu adanya kolaborasi yang antar mahasiswa dan dosen sehingga didapatkan multimedia yang sesuai harapan. Selain itu perlu adanya pembelajaran yang mengedepankan penggunaan elektronik secara maksimal. Karena selama ini pembelajaran masih berbasis teori dan praktek yang seakan memberi batas ruang dan waktu terhadap mahasiswa. Salah satunya pembelajaran berbasis Edmodo.

Edmodo merupakan media sosial berbasis lingkungan sekolah yang memberikan kemudahan terhadap guru (dosen), siswa (mahasiswa) dan orang tua untuk bisa saling terhubung. Edmodo adalah perusahaan teknologi pendidikan yang menawarkan alat komunikasi, kolaborasi, dan pembinaan untuk guru dan sekolah (Wikipedia, 2017). Di dalam media sosial itu sendiri telah disediakan berbagai macam menu yang dapat digunakan oleh guru (dosen) untuk mengefektifkan pembelajaran. Melalui media sosial ini pula mahasiswa tidak dibatasi lagi oleh ruang dan waktu dalam pembelajarannya. Karena selain dapat diakses melalui perangkat keras berupa komputer/ laptop juga dapat diakses melalui smartphone. Sehingga diharapkan kreativitas mahasiswa pada mata kuliah Pemrograman Komputer dalam pembuatan whiteboard animation semakin berkembang.

Penelitian ini bertujuan melihat kualitas produk media pembelajaran berbasis $E d$ modo yang telah dikembangkan. Pada penelitian ini lebih membahas tentang kepraktisan media pembelajaran berbasis Edmodo yang telah dikembangkan oleh dosen dan penggunaannya terhadap mahasiswa. Kepraktisan ini dilihat dari enam indikator yaitu senang, menyenangkan, menarik, bersemangat, dan mengerti Hobri, 2010.

\section{Metode Penelitian}

Penelitian ini dilaksanakan di program studi (prodi) Pendidikan Matematika Universitas Pekalongan. Objek yang digunakan adalah mahasiswa semester genap tahun akademik 2016/2017 yang mengambil mata kuliah Pemrograman Komputer.

Teknik pengumpulan data menggunakan angket (kuesioner) yang berisi beberapa pernyataan. Kuesioner (angket) merupakan teknik pengumpulan data yang dilakukan dengan cara memberi seperangkat pertanyaan atau pernyataan tertulis kepada responden untuk dijawabnya Sugiyono, 2010. Hal ini dimaksudkan untuk mengetahui respon mahasiswa terhadap media pembelajaran yang telah digunakan dalam proses pembelajaran.

Pernyataan dalam kuesioner disusun dari indikator yang ada. Indikator yang digunakan untuk mengetahui respon mahasiswa ada enam poin yaitu senang, menyenangkan, menarik, bersemangat, dan mengerti Hobri, 2010] . Setiap indikator memuat tiga hingga empat pernyataan sehingga total pernyataan yang digunakan sebanyak 20 butir dengan detail lengkapnya ada pada Tabel 1. Pedoman penskoran dalam angket memuat empat 
jawaban yaitu sangat setuju diberi skor 4 , setuju memiliki skor 3, kurang setuju 2, dan tidak setuju 1.

Tabel 1: Kisi-Kisi Angket Respon Mahasiswa

\begin{tabular}{|l|c|c|}
\hline No & Kriteria & No Butir \\
\hline 1 & Senang & $1,7,18$ \\
2 & Menyenangkan & $5,10,14$ \\
3 & Menarik & $6,7,9,19$ \\
4 & Bersemangat & $3,4,12$ \\
5 & Mengerti & $2,8,11$ \\
6 & Memudahkan & $3,15,16,20$ \\
\hline
\end{tabular}

Teknik analisis datanya yaitu dengan menjumlahkan keseluruhan skor yang diberikan mahasiswa untuk setiap item pernyataan. Selanjutnya memberi nilai kepraktisan dengan rumus sebagai berikut [Trianto, 2010]:

$$
\mathrm{RS}=\frac{\mathrm{A}}{\mathrm{B}} \times 100 \%
$$

Keterangan:

$$
\begin{aligned}
\mathrm{RS} & =\text { Rata-rata respon } \\
\mathrm{A} & =\text { Banyak mahasiswa yang merespon } \\
\mathrm{B} & =\text { Banyak mahasiswa yang memberikan respon }
\end{aligned}
$$

Respon mahasiswa dikatakan positif apabila persentase yang diperoleh lebih dari $80 \%$ dari rata-rata persentase setiap indikator Hobri, 2010].

\section{Hasil dan Pembahasan}

Hasil penelitian respon mahasiswa ini merupakan serangkaian kegiatan penelitian pengembangan media pembelajaran berbasis Edmodo. Angket diberikan kepada mahasiswa setelah adanya proses pembelajaran menggunakan media pembelajaran berbasis Edmodo pada mata kuliah Pemrograman Komputer. Hasil uji kepraktisan menunjukkan respon mahasiswa terhadap media pembelajaran berbasis Edmodo mencapai 81\%. Hal ini menunjukkan respon yang positif.

Terdapat beberapa pernyataan yang mencapai persentase lebih dari $85 \%$ berikut beberapa diantaranya. Pertama pada indikator senang butir pernyataan nomor satu menyatakan pembelajaran dengan media pembelajaran berbasis Edmodo membuat mahasiswa senang mencapai $88 \%$. Hal ini menunjukkan sebagian besar mahasiswa menyatakan sangat setuju atas pernyataan tersebut dikarenakan mahasiswa lebih merasa bebas dalam mempelajari materi tanpa dibatasi ruang dan waktu. Wulandari menyatakan minat belajar siswa dengan menggunakan Sparkol VideoScribe meningkat terutama apabila dilihat dari per-indikatornya [Wulandari, 2016]. Pada perasaan senang data menunjukkan dalam kategori sedang.

Kedua pada indikator menarik butir pernyataan nomor enam menyatakan media pembelajaran berbasis Edmodo merupakan hal yang baru dalam perkuliahan mencapai $86 \%$. Karena memang selama ini pembelajaran memadukan teori dan praktek tapi belum dilakukan secara maksimal. Berdasarkan hasil validasi ahli desain media pada pernyataan kemenarikan media terhadap siswa mencapai kriteria valid sebesar $80 \%$. Hal ini sesuai dengan penelitian Musyadat yang menunjukkan hasil kemenarikan media sebesar $80 \%$ Musyadat, 2015. Melalui Edmodo sebagai media sosial maka mahasiswa merasa lebih tertantang untuk mempelajarinya lebih lanjut. 
Selain itu masih ditemukan beberapa kelemahan yaitu mahasiswa merasa kurang betah mempelajari materi perkuliahan melalui media pembelajaran Edmodo dan mahasiswa merasa belum dimudahkan dengan menu-menu yang tersedia dalam media pembelajaran berbasis Edmodo terutama ketika berinteraksi dengan fasilitator dan teman lainnya. Hal ini dapat menjadi masukan pada pembelajaran selanjutnya untuk mengaktifkan dosen dan mahasiswa saling berinteraksi melalui media sosial Edmodo. Kemudian lebih memanfaatkan fitur orangtua yang ada dalam Edmodo sehingga dapat ikut memantau dan mendukung proses pembelajaran ketika di kelas.

\section{Simpulan dan Saran}

Simpulan dari hasil penelitian ini menyebutkan bahwa respon mahasiswa terhadap pengembangan media pembelajaran berbasis Edmodo mencapai 81\%, hal ini memberikan arah yang positif. Masih terdapat beberapa kekurangan yang perlu diperbaiki agar mendapatkan hasil yang maksimal.

\section{Referensi}

[Binanto, 2010] Binanto, I. (2010). IMultimedia Digital Dasar Teori + Pengembangannya. Andi, Yogyakarta.

[Hobri, 2010] Hobri (2010). Metodologi Penelitian Pengembangan (Aplikasi Pada Penelitian Pendidikan Matematika). Pena Salsabila, Jember.

[Musyadat, 2015] Musyadat, I. (2015). Pengembangan Media Pembelajaran Berbasis Video Scribe Untuk Peningkatan Hasil Belajar Pada Mata Pelajaran Sosiologi Kelas $\mathrm{X}$ MAN Bangli.

[Sugiyono, 2010] Sugiyono (2010). Metode Penelitian Pendidikan). Alfabeta, Bandung.

[Trianto, 2010] Trianto (2010). Mendesain Model Pembelajaran Inovatif dan Progresif. Kencana, Jakarta.

[Wulandari, 2016] Wulandari, D. A. (2016). Pengembangan Media Pembelajaran Menggunakan Sparkol VideoScribe Dalam Meningkatkan Minat Belajar Siswa Pada Pelajaran IPA Materi Cahaya Kelas VIII Di SMP Negeri 01 Kerjo Tahun Ajaran 2015/2016. 